\title{
Horn of Africa. The Major Factors in Regional (In)security
}

\author{
BÁLINT Tamás - ZSIFKó Mariann ${ }^{1}$
}

\begin{abstract}
Despite its strategic location, the area known as the Horn of Africa has become one of the most badly impacted areas of the African continent through its political and economic crises and humanitarian disasters. Since Siad Barre's fall, Somalia is an area of continuous civil war. The neighbouring countries - led by their own interests - directly and indirectly interfere in the internal affairs of Somalia. As part of this intervention, they have repeatedly attacked the terrorist organization called Al-Shabab. Because of pressure and support from the international community, the transitional government initiated numerous reforms, and by 2012 at the end of the transitional period a new Federal Constitution was adopted, the new Parliament was established with the election of the country's new President. However the new government still has to face tribal rivalry, extreme Islamist movements to stabilize its power.
\end{abstract}

During the Cold War period, peoples of Eastern Africa proclaimed and created their independent states within the boundaries drawn by the former colonialist powers. The security and economic situation of the freshly established Eastern African states depended largely on the support of the two super powers. In 1991, the uSA and the Soviet union both withdrew their support from the Somali government led by Siad Barre, thus prompting its fall, causing total chaos and the disruption of the political superstructure and unleashing a series of armed conflicts among the states in question.

In 1991, Somalia's north-western territory proclaimed its independence as the republic of Somaliland, while the north-eastern Puntland became an autonomous territory inside the state. A number of clans and extremist Islamist groups fought in the southern and south-eastern part of the country over the control of the area. In 2002, the Somali factions - except for Somaliland - signed a ceasefire agreement in eldoret, Kenya, which served as a basis for the Federal Constitution and for forming a Transitional Federal Government (TFG) and a Transitional Federal Assembly (TFA), in 2004. In 2006-2007, the so-called Supreme Council of Islamic Courts (SCIC) ${ }^{2}$ launched an attack against the TFG and its supporters and took control of the southern part of the country. The TFG asked for Ethiopian military assistance and together they managed to wear down the SCIC military force by the end of 2006, causing the organisation to dissolve ${ }^{3}$. The driving out of the Islamist extremists, however, resulted in increasing maritime piracy sanctioned by Sharia law ${ }^{4}$. It rendered the government's battle against the extremists more difficult as the government forces

1 Email: zsmariann1@yahoo.com

2 Formerly it had existed under the name of the union of Islamic Courts (uIC), which took control of Mogadishu in 2006. The uIC had consisted of 11 independent religious councils and had maintained tight relations with Al-Qaeda terrorist organisation.

3 It fell apart to the Alliance for the re-Liberation of Somalia, Djibouti and Asmara and the Shabab Militia (ras Kamboni Brigade of Shabab).

4 According to the report issued by the Maritime Bureau's Piracy reporting Centre, 111 out of the 298 anti-ship attacks took place in 2008 . 
were also composed of several clans, frequently clashing with each other ${ }^{5}$.

In 2008, the Djibouti wing of the anti-government Alliance for the Re-liberation of Somalia (ArS) signed a peace agreement with the TGF and took part even in the presidential elections of 2009. ArS-D ${ }^{6}$ leader Sheik Sharif Sheikh Ahmed won the presidential elections.

In 2008, Ethiopian troops withdrew from Somalia leading to a power vacuum in the country. The radical Islamist militias and clans immediately took advantage of the situation and attacked the joint TFG and AMISOM subunits ${ }^{7}$. In 2009, Al-Shabab ${ }^{8}$ militia launched a general offensive against Mogadishu, which the government was able to repel only with the assistance of the pro-government militias. Because of the sudden and large-scale deterioration in the security situation, President Sheik Sharif Sheikh Ahmed declared a state of emergency and asked for a military intervention of the neighbouring states.

In 2010, Al-Shabab carried out an attack in the ugandan capital claiming the life of 76 people and it intensified its attacks against the AMISOM troops. In addition, the terrorist organisation conducted a series of attacks on various institutions in Kenya kidnapping civilians there. As Al-Shabab gained ground, the chairperson of the African union (Au) Commission Jean Ping requested further reinforcements from a number of African countries ${ }^{9}$.

On 16 October 2011, Kenyan troops launched the "Operation Linda Nchi" (OLN: Protect the Nation $)^{10}$. A joint offensive of the TFG, AMISOM and Kenyan troops seriously damaged the capabilities of the terrorist organisation, driving its formations away from the greatest part of the territories under their control, thus forcing them to give up several settlements of strategic importance. Following the operation, Al-Shabab decided to modify its traditional fighting methods and opted for pursuing guerrilla warfare accompanied by terrorist actions.

In 2012, the Au once again requested the uN Security Council (uNSC) to contribute to an increase of the AMISOM personnel and provide further funds for stabilising the already achieved results and for expanding - in line with the strategic concept - the operational area. The uNSC issued its resolution No. $2036{ }^{11}$ proposing the increase of the AMISOM personnel. In the course of the II Somalia Conference held in Istanbul, the participants outlined that the country had entered into a new phase of peace building, and in the framework of this process efforts should be taken so that a new government could be elected.

In August and September 2012, the country officially declared its transitional period to be ended. The key milestones of this period were the adoption of the new Federal Constitution, the establishment of the new Parliament and the election of the country's new President.

\section{Risk factors}

In 2008, the uSA and uN sponsored Food Security Analysis Group stated that the number of refugees and displaced persons depending on humanitarian aid was radically increasing. Those leav-

5 An armed clash broke out between the fighters of the Marehan and Majerteen clans belonging to the $1^{\text {st }}$ Somali Brigade at the sieges of Kismayo in 2007.

6 ArS-D refers to the Djibouti wing of the Alliance for the re-liberation of Somalia.

7 The peacekeeping forces of the African union in Somalia are referred to as the African union Mission in Somalia (AMISOM).

8 Al-Shabab is the Somalia-based cell of the militant Islamist group al-Qaeda.

9 Angola, South Africa, Ghana, Guinea and Nigeria.

10 Its primary aim was to establish a buffer zone to a depth of $100 \mathrm{~km}$ from the Kenyan-Somali joint border, while the secondary one was to annihilate the armed groups of the al-Shabab movement.

11 resolution 2036 (2012): Security Council requests African union increase troop levels of Somalia Mission to 17,700, establishing expanded presence in keeping with Strategic Concept. 
ing their homes originated primarily from Central-Somalia and Puntland, which are famine and drought stricken territories. Accommodation and assistance of the refugees and displaced persons heavily burdens both Ethiopia and Kenya.

As from 2007, the famine, the withdrawal of the radical Islamic warriors, the inefficiency of the government forces in securing and protecting the maritime border and in preventing illegal fishing all have contributed to piracy gaining ground. The process was further strengthened by the fact that in Somali opinion the foreign fishing ships violated the country's territorial waters, thus any action against them was lawful. As a reaction to the Somali attacks against the foreign ships crossing the maritime area, the international community decided to send a naval force to the scene. ${ }^{12}$

relations between Puntland and Somaliland have remained unsettled. One of the main reasons for the conflict is the fact that neither side controls officially the Sool and Sanaag areas of disputed territorial status. The conflicting sides try to put pressure on each other by establishing local councils, launching limited attacks and concluding contradictory agreements, while the locals constantly change their civic allegiance. These efforts end up in armed conflicts, as a rule. The once British colony Somaliland insists on its independence, while Puntland supports the TFG.

The TFG armed forces are hastily organised and non-transparent both in their structure and in personnel, thus opening the way for corruption. The armed personnel still consist of clan $^{13}$ members in permanent rivalry with each other. Wavering loyalty and the insubordination of the TFG troops continues to pose a serious problem. ${ }^{14}$ ethiopia contributes to a significant extent to the training of the soldiers and equipping them with defence materials.

Since 2005, it has been a permanent challenge for the local powers to decide where to situate the headquarter of the government and its organs. In 2005, Jahwar and Baidoa were the capitals of the country, while in 2006 - due to yemeni pressure - the government finally decided to move to Baidoa. In 2007, several government organs removed to Mogadishu. In 2009, following the withdrawal of the Ethiopian troops, Al-Shabab troops and the forces of the Islamic Front of Somalia (IFS) occupied Baidoa, and so numerous parliamentary delegates left the country.

In 2007, the government started its reconciliation programme with the aim of getting the moderate SCIC members to join the TFA. In 2008, the ArS-D accepted the government conditions and formed a government of unity following the presidential elections. However, the rivalry among the clans loyal to the TFG cast a shadow on the reconciliation process. The opposition forces including the Al-Shabab terrorist organisation, the JIS, the Anole opposition group and the ArS-A decided to form the Islamic Party (Hisbi Islam/HI), which is still unwilling to reconcile with the government, its armed groups still attack the TFG forces and their supporters.

Moreover Somalia is characterised by extreme poverty, drought, famine and a largely destroyed infrastructure. At the same time, despite these enumerated problems, the country witnesses dynamic and lively economic activity, the reason for which is the fact that a number of Somali port cities ${ }^{15}$ represent an entry point for foreign goods to the entire network of African commerce. In addition, livestock breeding is also a key factor of the country's economic potential. The primary foreign markets of Somali livestock farming are the countries of the Arab Peninsula. The Gulf Countries ${ }^{16}$ profiting from Somalia's dependence significantly influence its politics and economics. The fi-

12 No.1816 uNSC resolution was taken in July 2008.

13 Majerteen sub-clan, Marehan clan, rahanwhein clan as well as the Abgal and Saad sub-clans of the Hawiye clan.

14 In 2008, a significant number of TFG fighters left the armed forces and joined the militias, and in a number of cases the soldiers denied carrying out the orders.

15 Mogadishu, Marka and Kismaayo.

16 Saudi Arabia, yemen and the united Arab Emirates. 
nancial assistance of the Somali Diaspora also significantly contributes to the country's economic output, performance and standard of living.

The anti-government armed groups continue to represent a serious threat to the government and its allies. The HI and its members are committed to their fight against the government and the international forces, and are not willing to reconcile with the government. For this reason, the HI permanently attacks the armed forces and civilian officials of the government. The financial assistance of the Diaspora is also a key factor of the financial resources of the government forces. ${ }^{17}$

\section{Reaction by the International Community}

The $\mathrm{uN}$ attempted to manage the deteriorating security situation in Somalia by setting up the $\mathrm{uN}$ Operation in Somalia (uNOSOM) in 1992. In support of the uN efforts, the uS launched its own Operation restore Hope, which later was integrated into the reorganised uNOSOM II operation. However, these operations failed to bring the expected results, taking a heavy toll on the side of the international forces. ${ }^{18}$ In 1995, the UN definitively withdrew its forces from the country. Since that time, it has taken political steps only to put pressure on the conflicting parties.

In 2009, the European union (Eu) started its training mission, the EuTM- ${ }^{19}$ in uganda with the aim to train the detached Somali forces in the framework of a thorough and high-quality training programme under the control of Eu and ugandan military advisors. The training mission proved to be inefficient due to the high costs of the training activity, the poor motivation of the Somali soldiers and their largely different religious background. Despite its obvious failure, the initiative proves that Europe is very interested in settling the security situation of the region.

In 2006, the Somali government asked for military protection from the Au and the Arab League and requested peacekeeping units to be deployed on Somali soil to take part in the establishment of its armed organisations. ${ }^{20}$ The Ethiopian government - as an Au member state - accepted the mission and marched into the country. Following the defeat of the SCIC, the Au remained committed to setting up a peacekeeping unit supported also by the uNSC.

Following the request, uganda and Burundi sent almost 2,350 troops to the country in 2007, while other donors ${ }^{21}$ failed to send troops in the framework of the AMISOM. ${ }^{22}$ The Au demanded $\mathrm{uN}$ participation in the mission, however it was ready to support the mission only with a smaller contingent of civilian and military advisors. ${ }^{23}$ In its No. 1772 uNSC resolution (2007), the uN reminded of the weaknesses of the AMISOM, thoroughly examined the available options for supporting its forces. Despite the Au demand, the uN decided not to take over the mission. In 2011, the $\mathrm{Au}$ initiated the units taking part in the operation OLN and joining the AMISOM.

17 Certain international organisations estimate the financial assistance from the Diaspora at a sum of 500 million and 1 billion uSD.

18 In 1993, 24 Pakistani and 18 US troops lost their lives in fighting with the Somali National Alliance.

19 The establishment of the European union Training Mission-I was endorsed by the uN in No. 1872 uNSC resolution in 2009.

20 In terms of their mandate, the Au troops are required to help the TFG in consolidating its control over the entire area of Somalia and are supposed to train the armed forces. The plan envisaged the deployment of three battalions in the area of Mogadishu and Kismaayo (II Sector). In the second phase, the plan envisaged deploying a force of six battalions all over Somalia, including the I and III sectors, except for Somaliland.

21 Nigeria, Ghana, Malawi.

22 Currently the AMISOM personnel totals almost 8,000 troops, including 3,520 soldiers from Burundi and 4,480 from uganda.

23 The uN peacemaking mission established in the country in the period from 1992 to 1995 (uNOSOM) was unable to perform its mission, due to its failure the $\mathrm{uN}$ did not want to get directly involved in the new mission. 
Somalia's foreign relations well reflect the territorial dividedness of the region. Puntland maintains good relations with Ethiopia, and is prone to frequently exploit its good ties with Addis Ababa even against Somaliland. Its informal relations with yemen make it possible for Puntland to discuss their fishing disputes. The US had continuously supported its intelligence service; however, because of increasing piracy, the relations between the $\mathrm{uS}$ and Puntland had become marginal.

Somaliland maintains low-level formal relations with Ethiopia. At the same time, the two countries signed a trade agreement in 2002. In terms of this agreement, Somaliland allows Ethiopia to use its port of Barbera. The inter-clan conflicts frequently spill over the frontiers. In 2008, the parties had talks on deepening their commercial and security relations. Somaliland has had several commercial disputes with Djibouti, yet following 2009, it intensified its economic, political and security relations with the country. South Africa has officially acknowledged the independence of Somaliland. The relations between the uSA and Somaliland are balanced, due to the close cooperation between the intelligence organisations of the two countries.

\section{International Organisations, Gulf Countries and China}

The TFG enjoys all-out support from a number of international organisations ${ }^{24}$ and from the neighbouring Arab states as well. The need for Somalia's territorial integrity and unity is emphasised first of all by egypt, Libya, Saudi Arabia and the United Arab emirates. Although the United Arab Emirates does not interfere in Somalia's internal affairs, it should be noted that the warlords controlling the country and their enterprises have their financial headquarters in Dubai.

The country signed a crude-oil extraction and exploitation agreement with China, and Chinese telecommunication companies are allowed to have a foothold in the capital. China supports the TFG with humanitarian and reconstruction assistance.

\section{Djibouti}

When proclaiming its independence, Somalia wanted to establish a Great Somalia by taking control of the former French colony, referred to as French Somalia, as well as Ethiopia and Kenya. After its war with Ethiopia in 1977, Somalia gave up its territorial claims, including those on Djibouti as well. In 2000, the relations between Djibouti and Somaliland became tense following the Reunification Conference of Arta, as Somaliland considered its secessionist efforts to be threatened by the conference. (For this reason it decided to boycott the event.) As a reaction to it, Djibouti decided to adopt numerous measures against the country. The Conference has negatively influenced the relations between ethiopia and Djibouti as well, since ethiopia saw its regional influence endangered by the initiative. On the other hand, their joint action against Eritrea ${ }^{25}$ diminished the tension between the two countries.

In 2006, Djibouti entered into agreement with the SCIC and the TFG, playing an important role in the negotiations between the TFG and the opposition.

\footnotetext{
$24 \mathrm{uNO}$, Arab League, Intergovernmental Authority on Development (IGAD), whose members are Djibouti, Eritrea, Ethiopia, Kenya, Somalia, Sudan and uganda. Its aim is to support the environmentally friendly attitude of the members and boost their economic, security and political cooperation.

25 Both Ethiopia and Djibouti have territorial claims on Eritrea.
} 


\section{Eritrea}

In the course of the eritrean-ethiopian War from 1998 to 2000, the conflicting sides - by exploiting the ethnic relations in the region - decided to arm some Somali groups. ${ }^{26}$ In 2001, Eritrea recognised the Somali Transitional National Government (TNG). However, the country was against establishing the TFG supported by Ethiopia. For this reason, Eritrea supported the SCIC with weapons and reinforcements in 2006, and after its defeat opted to supporting the ArS-A, ${ }^{27}$ as well as the Al-Shabab terrorist organisation and the JIS.

\section{Ethiopia}

The country supports the IGAD brokered Somali peace process, which lead to the TFG being formed in 2004. The SCIC has not acknowledged the TFG and has attacked its facilities and representatives. Following a request from the Au, Ethiopia marched into Somalia, mopped up the SCIC fighters and withdrew from the country in 2009.

Ethiopia's interference in Somalia was not a simple peace keeping operation but a possibility for the country to get rid of the Islamic extremist groups. Because of this threat, Ethiopia maintains close contact with the uS armed forces and carries out a series of covert operations against the groups of the Ogaden National Liberation Front (ONLF), which is an organisation supported by Somalia.

ethiopia makes efforts both through formal and informal channels to influence the TFG and Somaliland.

\section{Kenya}

Kenya - which has a large Somali ethnic minority population in significant territories in the country - is directly interested in settling the internal crisis in Somalia. Since the Somali uprising of the ' 60 s, the Kenyan majority identifies the ethnic group with extremist fighters and criminals. The situation is worsened by the fact that a large number of Somalis crossed the border and opted to live in refugee camps because of the ever-deepening internal crisis of Somalia. In many cases, the Somali extremists used these camps to carry out their actions against Somalia or the locals.

Moved by the serious problem, Kenya played an active role in the reunification and nation building initiatives. The country also acted as a mediator between the TNG and its opposition, as a result of which the sides signed the Nakaru agreement ${ }^{28}$ in 2001. Although the agreement proved to be a failure, it led to the formation of the TFG with Kenyan support.

It was a diplomatic success that in 2009 Kenya and Somalia signed a memorandum of understanding, in terms of which Kenya undertook to support the new government in a number of fields, including various technical, security, migration and economic issues of overriding importance.

As a consequence of the continuous Al-Shabab actions and at the request of the Au, Kenya started the OLN Operation on $16^{\text {th }}$ October 2011. Contrary to the unfavourable public reactions to Ethiopian military intervention, the Somali population accepted and supported the Kenyan military operations.

26 Somali middlemen armed the members of the Ethiopian Oromo Liberation Front (OLF), who attacked a series of Ethiopian targets from Somali territory.

27 Asmara wing of the Alliance for the re-liberation of Somalia.

28 The agreement aimed at establishing a new government. 


\section{USA}

Following the $\mathrm{uN}$ withdrawal in 1995, the uS played an active role in the training and operation of the local intelligence organisations. Washington supported the 2006 Ethiopian intervention with intelligence data. The uS and its European allies carry out permanent HuMINT and ELINT operations in the country because of the activity of the Al-Qaeda terrorist organisation. The uS Air Force carried out numerous air raids against supposed Al-Qaeda targets. ${ }^{29}$

The uSA supports the ongoing peace and nation building process in Somalia by all available means. At the reunification negotiations of eldoret in Kenya, the US put political pressure on the negotiating parties in order to enforce the agreement, in 2009 - following President Sheik Sharif Sheikh Ahmed's inauguration into office - Washington promised political support and financial assistance to the government.

\section{Conclusion}

After the fall of President Siad Barre, Somalia has live in ongoing civil war. During the civil war Somalia has broken into parts: Somaliland, Puntland and the clan dominated region. The transitional government and the international community is seeking to unite the country, but the rivalry between the clans and the activities of radical Islamic organizations antagonize it. After the rule of the colonial system the newly independent states try to live by their own strength occupying the neighbouring areas. Somalia's dream of Great Somalia inter alia led to a war with Ethiopia. The wars and anarchic situation were favourable for the strengthening of various paramilitary organizations and radical Islamic groups especially when supported by particular states both financially and technically, and the opposition in their neighbouring countries.

The security situation in Somalia posed a direct threat to Ethiopia and Kenya, as radical Islamic paramilitary militias gained considerable influence in much of Somalia's territory. ethiopia in 2006, and Kenya in 2011 intervened militarily in the internal affairs of Somalia, which has reduced the paramilitary militias' power and political influence. Another source of conflict is that eritrea supports radical Somali Islamic organizations.

After its unsuccessful operation (uNOSOM), the $\mathrm{uN}$ is trying to put political pressure on the parties in the conflict. It also supports the African Union's peace operation (AMISOM), which aims to ensure a peaceful transition, support the transitional governmental structures, implement a national security plan, train the Somali security forces, and secure humanitarian activities. As a result all of these efforts, by mid-2012 the milestones of a new political system were established.

Despite the progress achieved, the new leadership will continue to face the tribal conflicts and extremist Islamist movements, while the government should seek elimination of the high level corruption, stabilization of the security situation which will create a foundation for the development of the country, and overcome the drought, the high unemployment. all the factors that give basis for economic-driven piracy, social and humanitarian disasters.

Stabilizing the situation in Somalia is impossible without the collaboration of the Somali communities and without the direct support of the neighbouring countries and the international community - and as it is well-known, all kinds of problems and conflicts that go far beyond the borders of Africa's Horn.

29 The uSAF carried out an air raid against al-Qaeda members in March 2008, and killed one of the leaders of the AlShabab terrorist organisation in April 2008. 


\section{References}

Al-Shabaab (militant group). http://en.wikipedia.org/wiki/Al-Shabaab_\%28militant_group\%29 (23-012013)

Are the ugandan Terror Attacks a Sign of Things to Come from al Shabaab? http://www.issafrica.org/ iss_today.php?ID=983 (23-01-2013)

Kenya: Implications of the Military Offensive Against Al-Shabaab. http://allafrica.com/stories/201110250684.html (11-12-2012)

Killing of Fazul Abdullah Mohammed in Somalia a blow to Al Shabaab. http://www.issafrica.org/iss_today.php?ID=1305 (23-01-2013)

OLN, Operation Linda Inchi by Kenya; Ramifications on Geopolitics. http://www.horn.so/oln-operation-linda-inchi-by-kenya-ramifications-on-geopolitics (25-02-2013)

Operation Linda Nchi. http://www.criticalthreats.org/somalia/operation-linda-nchi (25-02-2013)

Post-election Violence in uganda unlikely. http://www.issafrica.org/iss_today.php?ID=1225 (17-122012)

PrOBÁLD Ferenc (Eds) (2002): Afrika és a Közel-Kelet földrajza. ELTE Eötvös Kiadó, Budapest, pp. 142-146.

Somalia Country Report. http://www.bti-project.de/fileadmin/Inhalte/reports/2012/pdf/BTI\%20 2012\%20Somalia.pdf(18-11-2012)

Somalia: Failed State and Failing responses. http://www.issafrica.org/iss_today.php?ID=1313 (25-022013)

Somalia's Islamist war chest being boosted by $\mathrm{uN}$ funds. http://www.telegraph.co.uk/news/worldnews/ africaandindianocean/somalia/9563506/Somalias-Islamist-war-chest-being-boosted-by-uN-funds. html (11-092012)

Somalia: To Intervene or Not. http://www.issafrica.org/iss_today.php?ID=1000 (30-10-2012) TADESSE, Eyassu (2009): Politikai hatalom és nemzeti identitás Afrika szarván. 141-149. In: CSIZ-

MADIA Sándor - TArróSy István (eds.): Afrika ma, Tradíció, Átalakulás, Fejlődés, Pécs.

The Damage Done By War in Somalia. http://www.issafrica.org/iss today.php?ID=1192 (19-12-2012)

united Nations Security Council resolutions. http://www.un.org/en/sc/documents/resolutions/ (28-122012) 